\title{
Trichoderma harzianum mutants enhance antagonism against phytopathogenic fungi, phosphorus assimilation and drought tolerance in Jalapeño pepper plants
}

\author{
Erika Cañada-Coyote ${ }^{1}$, Juan Gabriel Ramírez-Pimentel ${ }^{1}$, César Leobardo Aguirre-Mancilla ${ }^{1}$, \\ Juan Carlos Raya-Pérez ${ }^{1}$, Gerardo Acosta-García ${ }^{2}$, and Gabriel Iturriaga ${ }^{{ }^{*}}$ \\ ${ }^{1}$ Tecnológico Nacional de México/I.T. Roque, km 8 Carretera Celaya-Juventino Rosas, Celaya 38110, Guanajuato, México. \\ "Corresponding author (gaiturriaga@itroque.edu.mx). \\ ${ }^{2}$ Tecnológico Nacional de México/I.T. Celaya, Antonio García Cubas Pte. 600 esq. Av. Tecnológico, Celaya 38110, \\ Guanajuato, México.
}

Received: 17 December 2020; Accepted: 13 March 2021; doi:10.4067/S0718-58392021000300270

\begin{abstract}
The Trichoderma harzianum fungus is one of the most widely used biological control agents in agriculture. A new $T$. harzianum THITR01 strain was isolated and their spores were mutagenized with ethyl methane sulfonate obtaining 174 mutants. M7, M14, M21 and M24 are mutant strains that showed 97.4\%-100\% antagonist effect against Sclerotium rolfsii, Rhizoctonia solani and Sclerotinia sclerotiorum compared to the wild strain. Under potato dextrose agar (PDA) medium with either $\mathrm{NaCl}$, sorbitol or $\mathrm{NaHCO}_{3}$ there were nonsignificant growth rate differences between the mutants and the wild strain. M14 and M21 mutant strains were inoculated on 'Jalapeño' pepper plants (Capsicum anпиит L. var. annuит) with unavailable P promoted a significant increase in root fresh weight (54\% and 40\%, respectively) and dry weight (28\% in both strains), compared to plant inoculation with the wild strain. The M14 strain presented the highest P solubilization ability $\left(13.4 \mu \mathrm{g} \mathrm{g}^{-1}\right)$ in the substrate and promoted a change on root architecture. There was a higher relative water content (82.9\%) in drought stressed plants inoculated with the M24 mutant than in plants that were inoculated with the wild type strain (76.3\%), and also higher levels of proline in chili pepper plants inoculated with the M24 mutant (939.5 $\mu \mathrm{g} \mathrm{g}^{-1}$ dry weight) than in plants inoculated with the wild type strain (419.8 $\mu \mathrm{g} \mathrm{g}^{-1}$ dry weight). Therefore, M14, M21 and M24 mutant strains could potentially be used as biocontrol agents and plant protector from abiotic stress.
\end{abstract}

Key words: Abiotic stress, fungi, mutants, phosphorus, Trichoderma.

\section{INTRODUCTION}

Chemical pesticides have generated resistance, environmental pollution, and health problems due to their toxicity. For many years, biocontrol alternatives have been sought, to fight pests and plant diseases without damaging the environment, humans and crops. The Trichoderma genus includes species that adapt to different habitats, which have high specific growth rate and antagonist ability against phytopathogenic fungi such as Phytophthora, Rhizoctonia, Sclerotium, Pythium and Fusarium among others (Zin and Badaluddin, 2020). Trichoderma spp. inhibits pathogen growth by coiling around the host their hyphae with appressorium-like structures and triggering abundant secretion of lytic enzymes such as glucanases, chitinases, proteases and lipases causing cell wall breakdown of host fungi (Druzhinina et al., 2011; Wu et al., 2017). 
The genus Trichoderma is of great interest due to its direct-action mechanisms against phytopathogenic fungi (Baron et al., 2019). The fungus is able to control plant pathogens acting as antagonist using different mechanisms, such as competition for space and nutrients, mycoparasitism, antibiosis and secretion of hydrolytic enzymes, which cause vacuolization, cytoplasm disintegration and cell lysis of phytopathogenic fungi (Keswani et al., 2014; Zeilinger et al., 2016). In addition, T. harzianum has the ability to facilitate the solubilization and absorption of nutrient compounds for the plant such as $\mathrm{Cu}, \mathrm{P}, \mathrm{Fe}, \mathrm{Mn}, \mathrm{Na}$ and $\mathrm{N}$ (Vinale et al., 2013). Therefore, T. harzianum is widely used as a biocontrol and biofertilizer agent due to its beneficial interactions with plants, since it induces systemic resistance to pathogens and release compounds that promote plant growth and root development (Cai et al., 2015). Plant colonization by T. harzianum modulates endogenous plant hormones and antioxidants, compatible solutes, phytoalexins and phenolic compounds (Carvalhais et al., 2015).

There are reports of Trichoderma strains that improve tolerance to abiotic stress in plants such as cold, drought and salinity, through stimulation of root growth, improving photosynthetic efficiency, nutrient absorption and protecting the plant from oxidative damage more efficiently by eliminating reactive oxygen species (ROS) (Ahmad et al., 2015; Guler et al., 2016).

Several Trichoderma spp. can solubilize $\mathrm{P}$ for plant growth. This is a key element for plant nutrition and productivity and is mainly present in nucleic acids, phospholipids and ATP. The $\mathrm{P}$ is the second most limiting nutrient for crop production and is a non-renewable resource (Ham et al., 2018). Although total soil P is high, only $0.1 \%$ is available to plants due to rapid orthophosphate reactivity with soil minerals and bacteria conversion to organic forms that cannot be assimilated by plants, thus inorganic fertilizers supply this crop deficiency (Alori et al., 2017). However, excessive applications of fertilizers have led to water pollution and eutrophication (Hobbie et al., 2017). As an alternative, Trichoderma spp. have the ability to solubilize the soil P (Rawat and Tewari, 2011; Li et al., 2015).

In order to improve fungi performance, random mutagenesis experiments with ethyl methanesulfonate (EMS) have been successfully carried out to increase the secretion of extracellular enzymes in several filamentous fungi (Ribeiro et al., 2013). Trichoderma mutants have been described to improve their antagonism to phytopathogenic fungi using chemical mutagens (Singh et al., 2016), or T-DNA mutagenesis to promote tolerance to abiotic stress in plants (Guo et al., 2018).

The aim of the present study was to isolate T. harzianum mutants generated by EMS that improve their antagonist ability against plant pathogens, and also enhance their effect on plant stress tolerance and P solubilization. To accomplish this goal, various physiological and biochemical parameters in the isolated mutants and in the inoculated 'Jalapeño' pepper plants were determined. Our data provide novel mutants that could contribute to the use of field applications of Trichoderma fungus as a biocontrol agent.

\section{MATERIALS AND METHODS}

\section{Isolation of a new strain of Trichoderma harzianum}

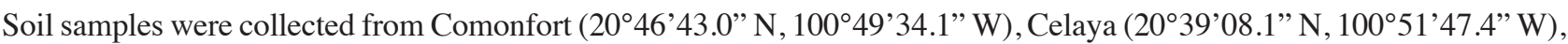
Juventino Rosas $\left(20^{\circ} 39^{\prime} 21.7^{\prime \prime} \mathrm{N}, 101^{\circ} 02^{\prime} 12.9^{\prime \prime} \mathrm{W}\right)$ and Apaseo el Alto $\left(20^{\circ} 26^{\prime} 38.7^{\prime \prime} \mathrm{N}, 100^{\circ} 37^{\prime} 40.9^{\prime \prime} \mathrm{W}\right)$ on the state of Guanajuato, Mexico. The method of serial dilutions and sowing on potato dextrose agar (PDA, BD Bioxon, Cuautitlán Izcalli, Mexico) supplemented with $0.48 \mathrm{mg} \mathrm{mL}^{-1}$ lactic acid and morphological identification, were used for the isolation of four strains of Trichoderma spp. The choice of the best antagonist strain was made by dual confrontation test against Fusarium oxysporum and Sclerotinia sclerotiorum selecting the strain with higher mycoparasitism ability, which led to the selection of a Trichoderma spp. strain labelled as THITR01. This strain is cryopreserved in the microbial collection of the División de Estudios de Posgrado e Investigación, Tecnológico Nacional de México/I.T. Roque, Celaya, México.

Molecular identification by an internal transcribed spacer (ITS) sequence was performed (Feitosa et al., 2019). For this purpose, the Trichoderma spp. strain THITR01 was grown in flasks containing $40 \mathrm{~mL}$ potato dextrose broth (PDB, BD Bioxon, Cuautitlán Izcalli, Mexico) medium for $72 \mathrm{~h}$ with constant stirring at $28^{\circ} \mathrm{C}$. The supernatant was eliminated, and the DNA extraction was carried out by the sodium dodecyl sulfate (SDS)-proteinase K method (Carpi et al., 2011). For the amplification of the internal transcribed regions the primers ITS5 (5'GGAAGTAAAAGTCGTAACAAGG3') and ITS4 (5'TCCTCCGCTTATTGATATGC3') were used. The amplification was carried out in a thermocycler (Techne, FTGENE5D, Cambridge, UK) by PCR under a 35 cycles program, in which each cycle consisted of the initial 
denaturation for $30 \mathrm{~s}$ at $94{ }^{\circ} \mathrm{C}$, the alignment of $1 \mathrm{~min}$ at $56^{\circ} \mathrm{C}$ and of $2 \mathrm{~min}$ at $72{ }^{\circ} \mathrm{C}$ for the extension. Sequencing results were aligned with the reported ITS sequence using NCBI BLAST algorithm (https://blast.ncbi.nlm.nih.gov/Blast. cgi?PROGRAM=blastn\&PAGE_TYPE=BlastSearch\&LINK_LOC=blasthome; National Center for Biotechnology Information [NCBI], Bethesda, Maryland, USA).

\section{Isolation of T. harzianum THITR01 mutants}

Trichoderma harzianum THITR01 spores were collected and their concentration was adjusted to $1 \times 10^{7}$ spores $\mathrm{mL}^{-1}$ and treated with 5\%,10\%,15\% and 20\% ethyl methanesulfonate (EMS) for 1,2 and $3 \mathrm{~h}$. Then, the spores were washed twice with sterile distilled water and serial dilutions were prepared. From the $10^{-3}$ dilution $200 \mu \mathrm{L}$ were taken and inoculated on PDA supplemented with sorbitol as a selection agent $(0.2,0.4$ and $0.6 \mathrm{M})$, incubating at $28{ }^{\circ} \mathrm{C}$. Fungal growth was monitored every $24 \mathrm{~h}$ under a microscope to observe spores that had the ability to germinate to be subcultured thereafter.

\section{Growth rate and antagonist potential of $T$. harzianum mutants}

To determine if the mutant's growth and sporulation ability were affected, six consecutive subcultures were carried out in PDA, discarding the strains with undesirable characteristics. From the normal growth and sporulation ability strains, the growth rate was determined placing a $0.5 \mathrm{~cm}$ disk in the center of PDA dishes and their radial growth was measured every $24 \mathrm{~h}$ after incubating at $28{ }^{\circ} \mathrm{C}$. The determination of the mutant's antagonist potential was determined by dual confrontation against Fusarium oxysporum, Sclerotium rolfsii, Rhizoctonia solani and Sclerotinia sclerotiorum, placing at one end of the $9 \mathrm{~cm}$ diameter Petri dish with PDA a $0.5 \mathrm{~cm}$ disk with active fungal growth of each of pathogen, and at the opposite end a disk with well-grown selected mutants and incubated at $28^{\circ} \mathrm{C}$. The growth rate of the phytopathogenic fungi was evaluated until $120 \mathrm{~h}$, and then the inhibition percentage of phytopathogens growth was calculated in triplicate.

\section{Growth of T. harzianum mutants under osmotic and alkaline stress}

From the antagonism tests previously described, five mutants were selected to determine tolerance to saline $(\mathrm{NaCl})$, alkaline $\left(\mathrm{NaHCO}_{3}\right)$ and osmotic (sorbitol) stress, and as control the wild strain (T. harzianum THITR01) and a T. harzianum commercial strain (Natucontrol-Biokrone, Mexico) were used. Mycelium discs of $0.5 \mathrm{~cm}$ diameter were taken from the edges of the fungal growth area and placed at the center of PDA dishes with $0.5,0.75$ or $1.25 \mathrm{M} \mathrm{NaCl}$ to assay salt stress; with $0.1 \%, 0.2 \%$ and $0.3 \% \mathrm{NaHCO}_{3}$ to test alkaline stress; or placed on with $0.75,1.0$ or $1.5 \mathrm{M}$ sorbitol to analyze osmotic stress, and incubated at $28{ }^{\circ} \mathrm{C}$. Colony diameter was recorded every $24 \mathrm{~h}$. The experiment was a randomized complete block with five replicates.

\section{Phosphorus solubilization ability of mutants}

To determine the T. harzianum mutant's ability to solubilize unavailable $\mathrm{P}$, the Pikovskaya (PVK)-agar culture medium containing $0.5 \mathrm{~g}\left(\mathrm{NH}_{4}\right)_{2} \mathrm{SO}_{4}, 0.2 \mathrm{~g} \mathrm{KCl}, 0.1 \mathrm{~g} \mathrm{MgSO}_{4} \cdot 7 \mathrm{H}_{2} \mathrm{O}, 0.002 \mathrm{~g} \mathrm{MnSO}_{4} \cdot \mathrm{H}_{2} \mathrm{O}, 0.2 \mathrm{~g} \mathrm{NaCl}, 10 \mathrm{~g}$ glucose and $0.002 \mathrm{~g}$ $\mathrm{FeSO}_{4} \cdot 7 \mathrm{H}_{2} \mathrm{O}$, supplemented with $0.5 \mathrm{~g}$ yeast extract and $20 \mathrm{~g}$ agar was used (Maurya et al., 2019). To this medium, $5 \mathrm{~g}$ $\mathrm{Ca}_{3}\left(\mathrm{PO}_{4}\right)_{2}$ were added as a source of unavailable $\mathrm{P}$ and $0.002 \mathrm{~g}$ bromocresol blue as an indicator of color change. For the test, $0.5 \mathrm{~cm}$ diameter discs with mycelium from the edges of the growth area of the five mutants were taken, including the wild type and the commercial strains as a control, and were placed in the center of the Petri dish and incubated at $28{ }^{\circ} \mathrm{C}$ during $12 \mathrm{~d}$.

\section{Phosphorus solubilization in planta}

Chili pepper (Capsicum аппиит L. var. аппиит) 'Jalapeño' seedlings were transplanted from the seedbed into pots with $300 \mathrm{~g}$ vermiculite and were immediately inoculated with $1 \mathrm{~mL} 1 \times 10^{7}$ spores of $T$. harzianum M5, M7, M14, M21 and M24 mutants, THITR01 wild type (WT), and commercial strain (C) on the plant stem close to the soil area, and watered at field capacity. A pot without microorganism (NT) was also included in the experiment. Fertilization was $20 \mathrm{~mL}$ of $0.5 \mathrm{~g}$ $\left(\mathrm{NH}_{4}\right)_{2} \mathrm{SO}_{4}, 0.2 \mathrm{~g} \mathrm{KCl}, 0.1 \mathrm{~g} \mathrm{MgSO}_{4} \cdot 7 \mathrm{H}_{2} \mathrm{O}, 0.002 \mathrm{~g} \mathrm{MnSO}_{4} \cdot \mathrm{H}_{2} \mathrm{O}, 0.002 \mathrm{~g} \mathrm{FeSO}_{4} \cdot 7 \mathrm{H}_{2} \mathrm{O}$ and in $5 \mathrm{~g} \mathrm{Ca}_{3}\left(\mathrm{PO}_{4}\right)_{2}$ as unavailable P. After $15 \mathrm{~d}$ plants were re-inoculated with the all-mentioned strains using the same spore concentration. For control (F) with available orthophosphate, the plants were watered with $50 \mathrm{~mL}$ of a solution containing $0.3 \mathrm{~g} \mathrm{NPK}$ (at 16-10-12+ microelements, Diamond mixture, ISAOSA, Jalisco, Mexico). The plant height was measured every week. At the end of 
the experiment, the vermiculite substrate of the different plant treatments was collected for the determination of available P with the Olsen method (Koralage et al., 2015), which consists of extraction of soil with $0.5 \mathrm{M} \mathrm{NaHCO}_{3}$ solution (pH adjusted to 8.5 ) for $30 \mathrm{~min}$ before filtration and thereafter the phosphate concentration is measured by atomic absorption spectrometry.

\section{Drought stress treatment in plants inoculated with mutant strains}

The chili pepper seedlings were transplanted from the seedbed into pots with a peat moss-vermiculite substrate mixture (3:1). M5, M7, M14, M21, M24 mutants, WT and C were inoculated at a concentration of $1 \times 10^{7}$ spores $\mathrm{mL}^{-1}$ (fertilized plant control $[\mathrm{F}]$ was not inoculated). All plants were watered at field capacity, and $15 \mathrm{~d}$ after transplanting they were re-inoculated with the same spore concentration as mentioned above except for F. After 2-mo, five plants from each experimental unit were randomly selected to determine agronomic parameters such as plant height, stem diameter, and plant and root fresh and dry weight. Thereafter watering was hold for $9 \mathrm{~d}$ and a sample was taken to determine chlorophyll and carotenoids (Guler et al., 2016), soluble phenols (Hura et al., 2012), relative water content (RWC) and proline (Salgado-Aguilar et al., 2020) and catalase activity (Singh et al., 2020).

\section{Data analysis}

The statistical analysis was performed with the SAS-University-Edition program (SAS Institute, Cary, North Carolina, USA), which consisted of ANOVA for experimental units in a completely randomized design with three replicates of two independent experiments, and comparison of means was determined by Tukey's test $(\mathrm{P} \leq 0.05)$.

\section{RESULTS AND DISCUSSION}

\section{Morphological and molecular identification of T. harzianum THITR01}

As a first step, four Trichoderma spp. strains identified by morphological and taxonomic characters were isolated and subjected to dual confrontation against $F$. oxysporum and $S$. sclerotiorum, selecting the strain THITR01 as the best antagonist (data not shown). By ITS PCR amplification, a DNA 535 bp fragment was obtained and a 99\% nucleotide sequence similarity with T. harzianum was found in an analysis by Blast (NCBI). The strain was registered in the NCBI with number MH282575 as T. harzianum THITR01.

\section{Selection of T. harzianum mutants}

Although currently site-directed mutagenesis is increasingly used in filamentous fungi, random mutagenesis continues to be a genome variation source that allows to broaden the desired phenotype of several fungi (Alfiky, 2019). Mutation with EMS is an empirical method where the higher the concentration and exposure time to the mutagenic agent, the greater the negative effect on the germination ability of T. harzianum spores. The 5\% EMS treatment of T. harzianum THITR001 during $1 \mathrm{~h}$, allowed the isolation of 174 mutants, which only 70 had radial growth. Other mutants had undesired morphological and sporulation changes. From these mutants only 25 had the ability to produce spores, the remaining 104 mutants had yeast-like thallus growth habit and were not considered for further testing.

\section{Mutants of T. harzianum have enhanced antagonist ability}

The T. harzianum potential as antagonist against different phytopathogens was evaluated by the growth rate and the dual confrontation test allowing the identification of 25 mutants that had a greater antagonist ability against pathogenic fungi. Initially, we measured $T$. harzianum mutants and the wild type strain growth rate (T. harzianum THITR001) as shown in Table 1. Most of them showed $2.13 \mathrm{~cm} \mathrm{~d}^{-1}$ growth rate except for M13, M15 and M20 that displayed 1.78, 1.77 and 0.70 $\mathrm{cm} \mathrm{d}^{-1}$ growth rate decrease respectively (Table 1 ).

When Sclerotium rolfsii was used to confront the M3, M7, M5, M14 and M21 mutants they inhibited 97.6\%, 97.4\%, 96.8\%, 95.9\% and $95.6 \%$ pathogen growth rate respectively, compared to the WT which promoted $95.0 \%$ growth rate inhibition. However, M13, M15 and M20 lost about half their antagonist ability against S. rolfsii, since they inhibited only $45.0 \%, 50.3 \%$ and $50.3 \%$ pathogen growth rate respectively. 
Table 1. Antifungal growth inhibition by Trichoderma harzianum mutants.

\begin{tabular}{|c|c|c|c|c|c|}
\hline \multirow[b]{2}{*}{ Mutant } & \multirow[b]{2}{*}{ Growth rate } & \multicolumn{4}{|c|}{ Growth inhibition } \\
\hline & & $\begin{array}{l}\text { Sclerotium } \\
\quad \text { rolfsii }\end{array}$ & $\begin{array}{c}\text { Sclerotinia } \\
\text { sclerotiorum }\end{array}$ & $\begin{array}{l}\text { Rhizoctonia } \\
\quad \text { solani }\end{array}$ & $\begin{array}{l}\text { Fusarium } \\
\text { oxysporum }\end{array}$ \\
\hline & $\mathrm{cm} \mathrm{d}^{-1}$ & 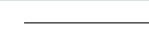 & - & 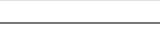 & - \\
\hline 1 & $2.13 \mathrm{c}$ & $90.0 \mathrm{bcd}$ & $80 \mathrm{~cd}$ & $75.6 \mathrm{ab}$ & $53.1 \mathrm{~b}$ \\
\hline 2 & $2.13 \mathrm{c}$ & 71.8abcd & $83.3 \mathrm{~cd}$ & $64.7 \mathrm{ab}$ & $51.3 \mathrm{~b}$ \\
\hline 3 & $2.13 \mathrm{c}$ & $97.6 \mathrm{~d}$ & $73.3 \mathrm{bcd}$ & $75.3 \mathrm{ab}$ & $50.0 \mathrm{~b}$ \\
\hline 4 & $2.13 \mathrm{c}$ & $93.8 \mathrm{~cd}$ & $86.7 \mathrm{~cd}$ & $90.0 \mathrm{ab}$ & $50.9 \mathrm{~b}$ \\
\hline 5 & $2.13 \mathrm{c}$ & $96.8 \mathrm{~d}$ & $95.0 \mathrm{~d}$ & $75.0 \mathrm{ab}$ & $54.4 \mathrm{~b}$ \\
\hline 6 & $2.13 \mathrm{c}$ & $95.9 \mathrm{~cd}$ & $75.0 \mathrm{bcd}$ & $78.5 \mathrm{ab}$ & $50.9 \mathrm{~b}$ \\
\hline 7 & $2.13 \mathrm{c}$ & $97.4 d$ & $100.0 \mathrm{~d}$ & $71.8 \mathrm{ab}$ & $51.6 \mathrm{~b}$ \\
\hline 8 & $2.13 \mathrm{c}$ & $93.5 \mathrm{~cd}$ & $66.7 \mathrm{bcd}$ & $60.6 \mathrm{a}$ & $52.5 b$ \\
\hline 9 & $2.13 \mathrm{c}$ & $80.8 \mathrm{~cd}$ & $76.7 \mathrm{bcd}$ & $72.4 \mathrm{ab}$ & $51.3 \mathrm{~b}$ \\
\hline 10 & $2.13 \mathrm{c}$ & $94.1 \mathrm{~cd}$ & $65.0 \mathrm{abcd}$ & $62.6 \mathrm{a}$ & $50.0 \mathrm{~b}$ \\
\hline 11 & $2.13 \mathrm{c}$ & $90.9 \mathrm{~cd}$ & $78.3 \mathrm{~cd}$ & $64.1 \mathrm{a}$ & $49.7 \mathrm{ab}$ \\
\hline 12 & $2.13 \mathrm{c}$ & $89.1 \mathrm{bcd}$ & $91.7 \mathrm{~d}$ & $64.7 \mathrm{ab}$ & $52.2 \mathrm{~b}$ \\
\hline 13 & $1.78 \mathrm{~b}$ & $45.0 \mathrm{a}$ & $25.0 \mathrm{ab}$ & 79.9ab & $54.7 \mathrm{~b}$ \\
\hline 14 & $2.13 \mathrm{c}$ & $95.9 \mathrm{~d}$ & $100.0 \mathrm{~d}$ & $63.8 \mathrm{a}$ & $51.6 \mathrm{~b}$ \\
\hline 15 & $1.77 \mathrm{~b}$ & $50.3 \mathrm{ab}$ & $13.3 \mathrm{a}$ & $61.8 \mathrm{a}$ & $53.1 \mathrm{~b}$ \\
\hline 16 & $2.13 \mathrm{c}$ & $81.3 \mathrm{~cd}$ & $100.0 \mathrm{~d}$ & $65.3 \mathrm{ab}$ & $51.3 \mathrm{~b}$ \\
\hline 17 & $2.13 \mathrm{c}$ & $90.3 \mathrm{~cd}$ & $95.0 \mathrm{~d}$ & $68.5 \mathrm{ab}$ & $55.3 \mathrm{~b}$ \\
\hline 18 & $2.13 \mathrm{c}$ & $93.8 \mathrm{~cd}$ & $90.0 \mathrm{~d}$ & 87.1ab & $51.3 \mathrm{~b}$ \\
\hline 19 & $2.13 \mathrm{c}$ & $90.0 \mathrm{~cd}$ & $85.0 \mathrm{~cd}$ & $67.6 \mathrm{ab}$ & $50.6 \mathrm{~b}$ \\
\hline 20 & $0.70 \mathrm{a}$ & $50.3 \mathrm{abc}$ & $36.7 \mathrm{abc}$ & $64.7 \mathrm{ab}$ & $42.2 \mathrm{a}$ \\
\hline 21 & $2.13 \mathrm{c}$ & $95.6 \mathrm{~d}$ & $100.0 \mathrm{~d}$ & $72.1 \mathrm{ab}$ & $53.4 \mathrm{~b}$ \\
\hline 22 & $2.13 \mathrm{c}$ & $90.3 \mathrm{~cd}$ & $96.7 \mathrm{~d}$ & $91.2 \mathrm{ab}$ & $53.8 \mathrm{~b}$ \\
\hline 23 & $2.13 \mathrm{c}$ & $91.5 \mathrm{~cd}$ & 65.0abcd & $100.0 \mathrm{~b}$ & $50.3 b$ \\
\hline 24 & $2.13 \mathrm{c}$ & $91.8 \mathrm{~cd}$ & $95.0 \mathrm{~d}$ & $100.0 \mathrm{~b}$ & $55.6 \mathrm{~b}$ \\
\hline 25 & $2.13 \mathrm{c}$ & $90.6 \mathrm{~cd}$ & $85.0 \mathrm{~cd}$ & $82.4 \mathrm{ab}$ & $50.6 \mathrm{~b}$ \\
\hline WT & $2.13 \mathrm{c}$ & $95.0 \mathrm{~cd}$ & $93.3 \mathrm{~d}$ & $77.1 \mathrm{ab}$ & $52.2 \mathrm{~b}$ \\
\hline
\end{tabular}

WT: Trichoderma harzianum THITR01 wild type strain.

Values are means of five biological replicates. For each column, values followed by different letters are significantly different according to Tukey’s test $(\mathrm{P} \leq 0.05)$.

Figure 1. Dual confrontation of Trichoderma harzianum mutants against Sclerotium rolfsii after $7 \mathrm{~d}$ incubation at $28{ }^{\circ} \mathrm{C}$ on PDA medium. M1 to M25: T. harzianum mutants; WT: T. harzianum THITR01 wild type strain; P: $S$. rolfsii.

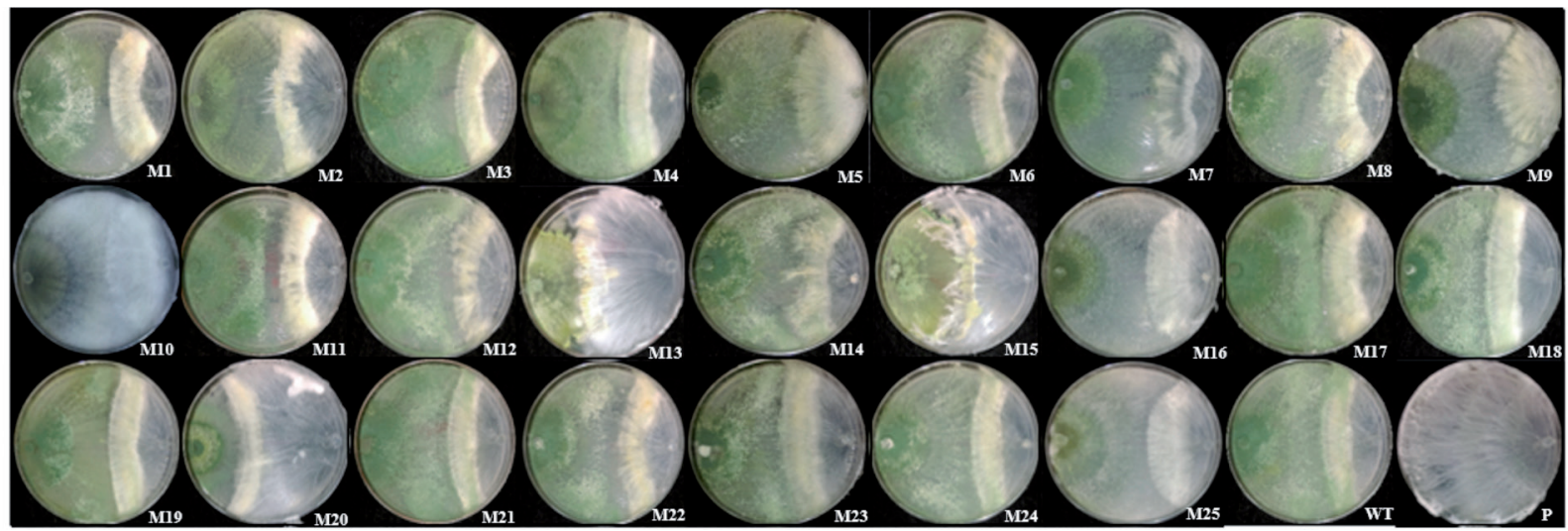

From the dual confrontation test of $T$. harzianum mutants against $S$. rolfsii, a clearly identified hyphae and sporulation zone of the different mutants and S. rolfsii hyphae could be observed (Figure 1). Concerning M13, M15 and M20 mutants, the pathogen mycelium grew over the mutant's mycelia as shown in Figure 1. 
When S. sclerotiorum was confronted with the T. harzianum M5, M7, M12, M14, M16, M17, M18, M21, M22 and M24 mutants, they inhibited 90\%-100\% the pathogen growth, which is comparable to WT 93.3\% growth rate inhibition and all them belonged to the same statistical group $(\mathrm{P} \leq 0.05)$. In contrast, M13, M15 and M20 decreased their antagonist ability against $S$. sclerotiorum to $25.0 \%, 13.3 \%$ and $36.7 \%$ growth rate respectively (Table 1 ). When $R$. solani was confronted against M23 and M24 mutants, it showed 100\% growth rate inhibition, compared to $77.1 \%$ growth rate inhibition against WT. If $F$. oxysporum was used against all the $T$. harzianum mutants, they displayed $49.6 \%$ antagonistic ability compared to $52.2 \%$ for the WT and belong to the same statistical group ( $\mathrm{P} \leq 0.05)$ except for M20 mutant which inhibited $42.2 \%$ pathogen growth rate. These described mutants had a higher growth rate inhibition ability against pathogens than the Trichoderma mutants reported by Alfiky (2019), where spore mutagenesis by ultraviolet light radiation of Trichoderma virens and T. asperellum allowed the selection of $T$. virens mutants that inhibited $76.6 \%$ and $78.3 \%$ growth rate of $S$. rolfsii and $R$. solani respectively, whereas T.asperellum mutants displayed $56.7 \%$ and $56.3 \%$ growth rate inhibition ability against those phytopathogen fungi $7 \mathrm{~d}$ after confrontation (Alfiky, 2019). Similarly, T. harzianum mutants obtained by gamma radiation displayed $48.13 \%$ and $88.40 \%$ antagonist ability against $R$. solani and $S$. sclerotiorum, respectively, after $3 \mathrm{~d}$ of confrontation (Abbasi et al., 2016). These two reports showed a lower antagonist ability than the mutant described in the present work.

\section{Trichoderma harzianum mutant's growth under osmotic and alkaline conditions}

The 25 isolated mutants in this study were subjected to different $\mathrm{NaCl}$ concentrations to test their possible salt-stress tolerance (Table 2). We assayed T. harzianum growth rate at $0.50,0.75$ and $1.25 \mathrm{M} \mathrm{NaCl}$ for the different strains, however there were nonsignificant $(\mathrm{P} \leq 0.05)$ differences between the mutants and $\mathrm{WT}$ and $\mathrm{C}$ at any of the mentioned $\mathrm{NaCl}$ concentrations. We observed that the mycelium radial growth remained constant; however, the spore production capacity was inhibited under the different $\mathrm{NaCl}$ concentrations. Poosapati et al. (2014) found natural isolates of Trichoderma strains that could tolerate up to $1 \mathrm{M} \mathrm{NaCl}$.

To further characterize Trichoderma mutants, they were subjected to osmotic stress. All mutant grew at 0.75 and $1.0 \mathrm{M}$ sorbitol, however the growth rate did not show significant $(\mathrm{P} \leq 0.05)$ differences compared to WT but it was higher than C. At $1.5 \mathrm{M}$ sorbitol there were nonsignificant $(\mathrm{P} \leq 0.05)$ differences between the mutants, WT and $\mathrm{C}$ (Table 2).

Lastly, alkaline tolerance was tested. It was found that at $0.1 \%, 0.2 \%$ and $0.3 \% \mathrm{NaHCO}_{3}$ all mutants showed a significantly $(\mathrm{P} \leq 0.05)$ similar growth rate compared to WT (Table 2). Guo et al. (2018) reported the construction of a T-DNA insertion mutant library, yielding 65 T. asperellum mutants, the T59 mutant could tolerate up to $1.7 \mathrm{M} \mathrm{NaCl}$ and $\mathrm{T} 3$ and $\mathrm{T} 5$ mutants could grow on $0.4 \% \mathrm{NaHCO}_{3}$. Alkaline soils are common in arid and semi-arid regions accounting around $25 \%$ of our planet's surface.

\section{Trichoderma harzianum mutants solubilize $\mathbf{P}$}

Trichoderma harzianum is an efficient biocontrol agent that promotes plant growth and enhances nutrients uptake by plants (Rawat and Tewari, 2011; Li et al., 2015). Therefore, it was decided to evaluate the ability of T. harzianum mutants to solubilize $\mathrm{Ca}_{3}\left(\mathrm{PO}_{4}\right)_{2}$ as a source of unavailable P. The M14 mutant and THITR01 WT showed $\mathrm{Ca}_{3}\left(\mathrm{PO}_{4}\right)_{2}$ solubilizing capacity $7 \mathrm{~d}$ after growth in PVK-agar, since a color change was observed due to the excretion of organic acids from a blue to yellow tone because of a change in $\mathrm{pH}$ visualized by the bromocresol green dye (Figure 2). In contrast, $\mathrm{C}$ was unable to

Table 2. Growth rate of Trichoderma harzianum mutants under salt, osmotic and alkaline stress.

\begin{tabular}{|c|c|c|c|c|c|c|c|c|c|}
\hline \multirow[b]{2}{*}{ Strains } & \multicolumn{3}{|c|}{$\mathrm{NaCl}$} & \multicolumn{3}{|c|}{ Sorbitol } & \multicolumn{3}{|c|}{$\mathrm{NaHCO}_{3}$} \\
\hline & $0.5 \mathrm{M}$ & $0.75 \mathrm{M}$ & $1.25 \mathrm{M}$ & $0.75 \mathrm{M}$ & $1.0 \mathrm{M}$ & $1.5 \mathrm{M}$ & $0.1 \%$ & $0.2 \%$ & $0.3 \%$ \\
\hline & \multicolumn{3}{|c|}{$\longrightarrow \mathrm{cm} \mathrm{d}^{-1} \longrightarrow$} & \multicolumn{3}{|c|}{$\longrightarrow \mathrm{cm} \mathrm{d}^{-1} \longrightarrow$} & \multicolumn{3}{|c|}{$\longrightarrow \mathrm{cm} \mathrm{d}^{-1}$} \\
\hline M5 & $1.28 \mathrm{~b}$ & $0.82 \mathrm{bc}$ & $0.23 b c$ & $1.42 \mathrm{~b}$ & $1.35 b$ & $0.58 \mathrm{a}$ & $1.48 \mathrm{c}$ & $1.36 \mathrm{c}$ & $1.14 \mathrm{~d}$ \\
\hline M7 & $1.28 \mathrm{~b}$ & $0.93 c$ & $0.24 b c$ & $1.42 \mathrm{~b}$ & $1.35 \mathrm{~b}$ & $0.64 \mathrm{a}$ & $1.43 \mathrm{c}$ & $1.37 \mathrm{c}$ & $0.98 \mathrm{~cd}$ \\
\hline M14 & $1.33 \mathrm{~b}$ & $0.72 \mathrm{ab}$ & $0.23 b c$ & $1.42 \mathrm{~b}$ & $1.32 \mathrm{~b}$ & $0.63 \mathrm{a}$ & $1.43 \mathrm{c}$ & $1.27 \mathrm{c}$ & $1.11 \mathrm{~d}$ \\
\hline M21 & $1.07 \mathrm{a}$ & $0.86 \mathrm{bc}$ & $0.21 \mathrm{~b}$ & $1.42 \mathrm{~b}$ & $1.37 \mathrm{~b}$ & $0.64 \mathrm{a}$ & $1.27 \mathrm{ab}$ & $0.87 \mathrm{~b}$ & $0.73 b c$ \\
\hline M24 & $1.15 \mathrm{ab}$ & $0.64 \mathrm{a}$ & $0.13 \mathrm{a}$ & $1.40 \mathrm{~b}$ & $1.29 \mathrm{~b}$ & $0.60 \mathrm{a}$ & $1.37 \mathrm{bc}$ & $0.89 \mathrm{~b}$ & $0.56 \mathrm{~b}$ \\
\hline WT & $1.34 \mathrm{~b}$ & $0.86 \mathrm{bc}$ & $0.27 b$ & $1.42 \mathrm{~b}$ & $1.30 \mathrm{~b}$ & $0.67 \mathrm{a}$ & $1.46 \mathrm{c}$ & $1.28 \mathrm{c}$ & $0.88 \mathrm{bcd}$ \\
\hline C & $1.28 \mathrm{~b}$ & $0.84 b c$ & $0.31 \mathrm{c}$ & $1.26 \mathrm{a}$ & $1.04 \mathrm{a}$ & $0.60 \mathrm{a}$ & $1.15 \mathrm{a}$ & $0.62 \mathrm{a}$ & $0.19 \mathrm{a}$ \\
\hline
\end{tabular}

M5, M7, M14, M21, M24: Mutant strains; WT: THITR01 wild type strain; C: commercial strain.

Values are means of five biological replicates. For each column, values followed by different letters are significantly different according to Tukey's test $(\mathrm{P} \leq 0.05)$. 
Figure 2. Phosphorus solubilization by Trichoderma harzianum strains on PVK-agar media. Growth medium without fungus (A), commercial strain (B), THITR01 wild type strain (C), and M14 mutant (D).

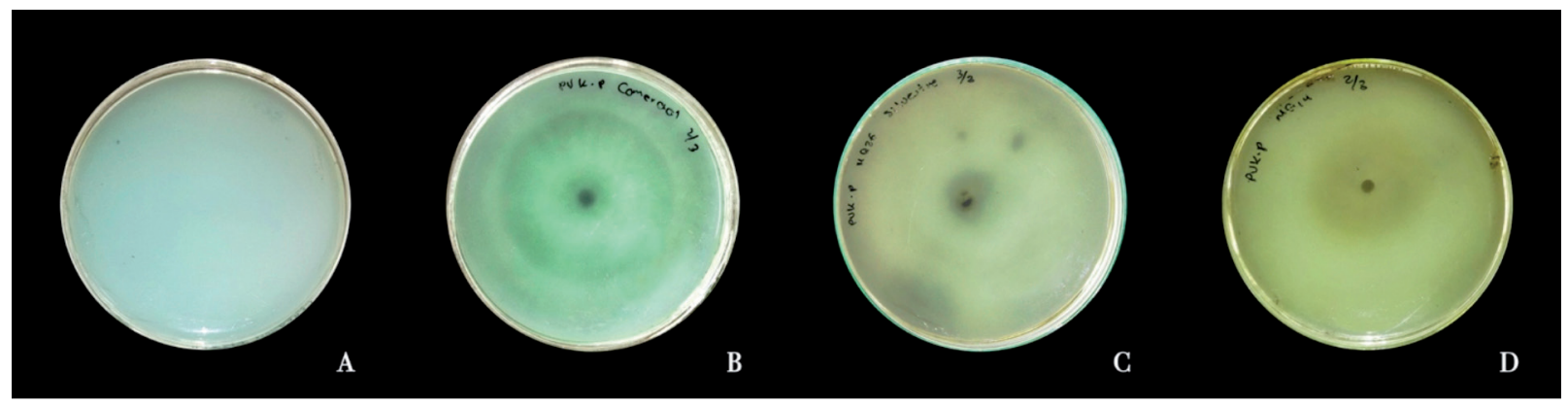

promote $\mathrm{P}$ solubilization (Figure 2). The M21 mutant strain also showed this solubilization ability, however it was lower compared to M14; whereas M5, M7 and M24 mutants did not show P solubilization (data not shown). Similar $\mathrm{Ca}_{3}\left(\mathrm{PO}_{4}\right)_{2}$ solubilization effect was previously reported in another T. harzianum strains (Alori et al., 2017).

\section{Mutant strains solubilize $\mathbf{P}$ in chili pepper plants}

The effect of T. harzianum mutants on the agronomic parameters of inoculated plants with unavailable $\mathrm{P}$ was determined. There were nonsignificant differences $(\mathrm{P} \leq 0.05)$ in shoot elongation (plant height, plant fresh and dry weight) after inoculation of chili pepper plants with the mutant and WT. Plant responses to low P availability are displayed at root architecture level (Niu et al., 2013). It was found that the M7 and M24 mutants, $\mathrm{C}$ and NT had significant $(\mathrm{P} \leq 0.05)$ capacity to induce root elongation displaying 26.4 and $29.0,25.3$ and $28.4 \mathrm{~cm}$ respectively after 2-mo, whereas inoculation with the other mutants and WT did not promote significantly root elongation (Table 3 ). However, regarding plant biomass analysis it was observed that inoculation with the M14 and M21 mutants led to significant $(\mathrm{P} \leq 0.05)$ increases of 2.6 and $2.0 \mathrm{~g}$ respectively of root fresh weight and $0.28 \mathrm{~g}$ dry weight corresponding to both mutants, compared to plant inoculation with WT (Table 3). These data are consistent with previous reports where root development and P solubilization are induced by $T$. harzianum inoculation (Li et al., 2015).

Another important effect on chili pepper plants inoculated with $T$. harzianum mutants and grown with unavailable $\mathrm{P}$, was a change in the root architecture (Figure 3). As shown in Table 3, there were found significant $(P \leq 0.05)$ changes in root length on plants inoculated with the mutant strains compared to inoculation with WT. An increase in lateral root formation and root hairs elongation compared to treatment with chemical fertilization and treatment without T. harzianum was observed (Figure 3). These root morphological changes were more evident on plants inoculated with M14 compared to inoculation with WT or C (Figure 3). Similar alterations in root architecture in Pinus sylvestris seedlings promoted by Trichoderma spp. inoculation have already been described and correlate with higher P solubilization (Halifu et al., 2019).

Table 3. Effect of Trichoderma harzianum mutants on the agronomic parameters of inoculated 'Jalapeño' pepper plants with unavailable $P$.

\begin{tabular}{|c|c|c|c|c|c|c|}
\hline \multirow[b]{2}{*}{ Treatments } & \multicolumn{2}{|c|}{ Fresh weight } & \multicolumn{2}{|c|}{ Dry weight } & \multicolumn{2}{|c|}{ Length } \\
\hline & Shoot & Root & Shoot & Root & Shoot & Root \\
\hline M5 & $1.7 \mathrm{a}$ & $1.3 \mathrm{bc}$ & $0.22 \mathrm{a}$ & $0.17 \mathrm{bc}$ & $14.4 \mathrm{~cd}$ & $21.7 \mathrm{ab}$ \\
\hline M7 & $2.1 \mathrm{ab}$ & $1.6 \mathrm{~cd}$ & $0.25 \mathrm{ab}$ & $0.18 \mathrm{bcd}$ & $12.8 \mathrm{bc}$ & $26.4 \mathrm{cde}$ \\
\hline M14 & $3.0 \mathrm{~d}$ & $2.6 \mathrm{e}$ & $0.40 \mathrm{~d}$ & $0.28 \mathrm{e}$ & $13.5 \mathrm{bcd}$ & $24.4 \mathrm{abc}$ \\
\hline M21 & $2.8 \mathrm{~cd}$ & $2.0 \mathrm{~d}$ & $0.35 \mathrm{c}$ & $0.28 \mathrm{e}$ & $15.1 \mathrm{~d}$ & $25.1 \mathrm{bcd}$ \\
\hline M24 & $2.2 \mathrm{ab}$ & $1.4 \mathrm{bc}$ & $0.26 \mathrm{ab}$ & $0.16 \mathrm{bc}$ & $12.8 \mathrm{bc}$ & $29.0 \mathrm{e}$ \\
\hline WT & $3.1 \mathrm{~d}$ & $1.2 \mathrm{bc}$ & $0.40 \mathrm{~d}$ & $0.20 \mathrm{~cd}$ & $13.5 \mathrm{bcd}$ & $23.3 \mathrm{abc}$ \\
\hline $\mathrm{C}$ & $2.5 b c$ & $1.0 \mathrm{~b}$ & $0.28 b$ & $0.15 b$ & $12.2 \mathrm{ab}$ & $25.3 \mathrm{bcde}$ \\
\hline NT & $3.2 d$ & $1.5 \mathrm{bcd}$ & $0.39 \mathrm{~cd}$ & $0.21 \mathrm{~d}$ & $12.9 \mathrm{bc}$ & $28.4 \mathrm{de}$ \\
\hline $\mathrm{F}$ & $3.3 \mathrm{~d}$ & $0.4 \mathrm{a}$ & $0.36 \mathrm{~cd}$ & $0.09 \mathrm{a}$ & $10.6 \mathrm{a}$ & $20.8 \mathrm{a}$ \\
\hline
\end{tabular}

M5, M7, M14, M21, M24: Mutant strains; WT: THITR01 wild type strain; C: commercial strain; NT: uninoculated plants; F: fertilized control.

Values are means of five biological replicates. For each column, values followed by different letters are significantly different according to Tukey's test $(\mathrm{P} \leq 0.05)$. 
Figure 3. Effect of Trichoderma harzianum mutants on root architecture of 2-mo-old 'Jalapeño' chili pepper plants grown with unavailable $\mathbf{P}$.

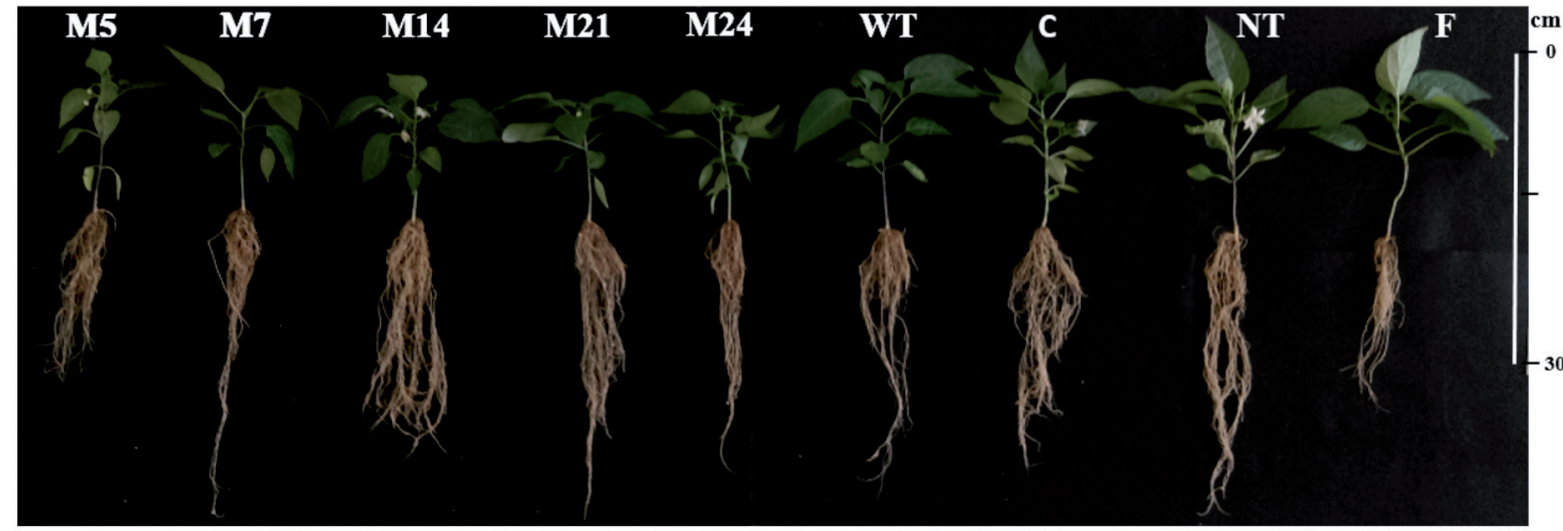

M5, M7, M14, M21, M24: Mutant strains; WT: THITR01 wild type strain: C: commercial strain; NT: uninoculated plants; F: fertilized control.

Photograph shows representative plants from each treatment.

Also, we determined the available $\mathrm{P}$ in the vermiculite substrate of inoculated plants to assess the mineral solubilization by Trichoderma mutants. There were significant $(\mathrm{P} \leq 0.05)$ differences between mutants and WT, the M7 and M14 mutant solubilized 10.9 and $13.4 \mu \mathrm{g} \mathrm{g}^{-1} \mathrm{P}$ in the substrate respectively compared to the other mutants and controls (Figure 4). The P solubilization improves the biological $\mathrm{N}$ fixation, the phytohormones synthesis and the availability of other nutrients (Alori et al., 2017).

\section{Mutant strains mitigate drought stress in chili pepper plants}

First of all, the effect of inoculating chili pepper plants with T. harzianum mutants was evaluated regarding various agronomic parameters. It was found that there were nonsignificant $(\mathrm{P} \leq 0.05)$ differences in plants inoculated with the different T.harzianum strains (mutants, WT or C), compared to the plants without inoculation with T.harzianum, regarding shoot or root growth and stem diameter (Table 4). These data indicate the T. harzianum strains used in this work do not function as promoters of plant growth, in contrast to other reports (Contreras-Cornejo et al., 2014; Ahmad et al., 2015).

In addition to the role of T. harzianum as a biocontrol agent against fungal diseases in plants, it has recently been reported that this fungus is also able to protect plants from cold, heat, salinity or drought stress (Ahmad et al., 2015; Guler et al., 2016). Therefore, this study analyzed whether there was a greater tolerance to drought stress in chili pepper plants

Figure 4. Quantification of available $P$ in substrate of 'Jalapeño' pepper plants grown with unavailable $P$ and inoculated with Trichoderma harzianum strains.

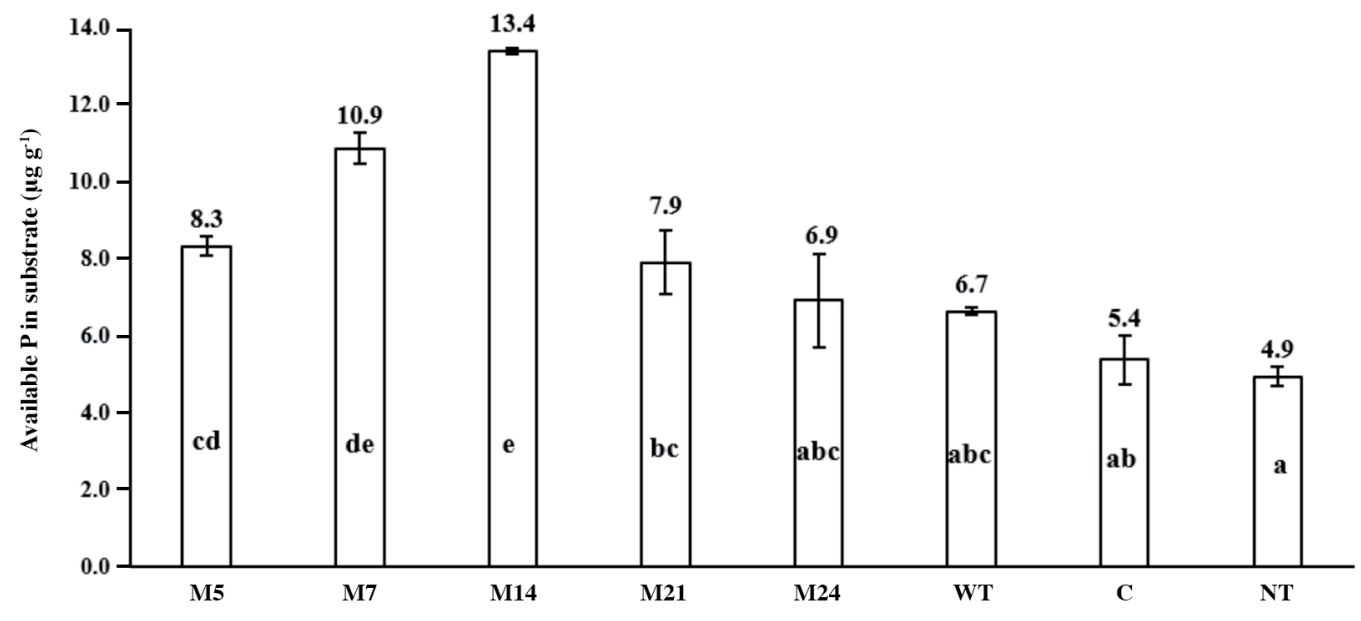

M5, M7, M14, M21, M24: Mutant strains; WT: THITR01 wild type strain; C: commercial strain; NT: uninoculated plants. The values represent the mean \pm SE $(n=5)$. Different letters indicate significant differences between treatments according to Tukey's test $(\mathrm{P} \leq 0.05)$. 
Table 4. Effect of Trichoderma harzianum inoculation on 'Jalapeño' pepper plants growth.

\begin{tabular}{|c|c|c|c|c|c|c|c|}
\hline \multirow[b]{2}{*}{ Strains } & \multicolumn{2}{|c|}{ Fresh weight } & \multicolumn{2}{|c|}{ Dry weight } & \multicolumn{2}{|c|}{ Length } & \multirow[b]{2}{*}{ Diameter } \\
\hline & Shoot & Root & Shoot & Root & Shoot & Root & \\
\hline & & 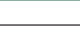 & 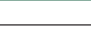 & 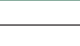 & 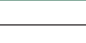 & 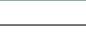 & $\mathrm{cm}$ \\
\hline M5 & $10.52 \mathrm{a}$ & $4.43 \mathrm{a}$ & $1.34 \mathrm{a}$ & $0.47 \mathrm{a}$ & $36.4 \mathrm{a}$ & $26.1 \mathrm{a}$ & $0.7 \mathrm{a}$ \\
\hline M7 & $9.77 \mathrm{a}$ & $4.30 \mathrm{a}$ & $1.28 \mathrm{a}$ & $0.50 \mathrm{a}$ & $33.6 \mathrm{a}$ & $27.9 \mathrm{a}$ & $0.7 \mathrm{a}$ \\
\hline M14 & $10.07 \mathrm{a}$ & $4.07 \mathrm{a}$ & $1.21 \mathrm{a}$ & $0.54 \mathrm{a}$ & $37.8 \mathrm{a}$ & $24.7 \mathrm{a}$ & $0.8 \mathrm{a}$ \\
\hline M21 & $10.42 \mathrm{a}$ & $3.85 \mathrm{a}$ & $1.37 \mathrm{a}$ & $0.54 \mathrm{a}$ & $38.3 \mathrm{a}$ & $25.3 \mathrm{a}$ & $0.8 \mathrm{a}$ \\
\hline M24 & $10.85 \mathrm{a}$ & $4.51 \mathrm{a}$ & $1.27 \mathrm{a}$ & $0.54 \mathrm{a}$ & $35.0 \mathrm{a}$ & $26.0 \mathrm{a}$ & $0.7 \mathrm{a}$ \\
\hline WT & $10.47 \mathrm{a}$ & $3.20 \mathrm{a}$ & $1.28 \mathrm{a}$ & $0.47 \mathrm{a}$ & $39.0 \mathrm{a}$ & $26.5 \mathrm{a}$ & $0.7 \mathrm{a}$ \\
\hline $\mathrm{C}$ & $11.6 \mathrm{a}$ & $3.75 \mathrm{a}$ & $1.43 \mathrm{a}$ & $0.54 \mathrm{a}$ & $34.2 \mathrm{a}$ & $26.9 a$ & $0.8 \mathrm{a}$ \\
\hline NT & $12.13 \mathrm{a}$ & $3.56 \mathrm{a}$ & $1.45 \mathrm{a}$ & $0.51 \mathrm{a}$ & $40.8 \mathrm{a}$ & $24.5 \mathrm{a}$ & $0.7 \mathrm{a}$ \\
\hline
\end{tabular}

M5,M7, M14, M21, M24: Mutant strains; WT: THITR01 wild type strain; C: commercial strain; NT: uninoculated plants. Values are means of five biological replicates. For each column, values followed by different letters are significantly different according to Tukey's test $(\mathrm{P} \leq 0.05)$.

inoculated with T. harzianum mutants. After $9 \mathrm{~d}$ without irrigation, a significant $(\mathrm{P} \leq 0.05)$ higher relative water content (RWC) in plants inoculated with the M24 mutant was found, compared to plants inoculated with WT or C (Table 5). Also, there was a higher RWC in plants inoculated with all the strains than in plants without fungus inoculation (Table 5). Our data with the T. harzianum mutants is similar to previous reports where plants inoculated with Trichoderma strains improved their stress tolerance (Guler et al., 2016). Barros et al. (2018) described that Cinophalla flexuosa inoculated with mycorrhiza subjected to $7 \mathrm{~d}$ of drought stress had a higher RWC than without mycorrhiza.

Interestingly, after $9 \mathrm{~d}$ of drought stress chlorophyll a, chlorophyll $\mathrm{b}$ and total chlorophyll contents showed a significant ( $\mathrm{P} \leq 0.05$ ) increase of $14.5,10.5$ and $25.0 \mathrm{mg} \mathrm{g}^{-1}$ dry weight, respectively, in plants inoculated with the T. harzianum WT compared to the inoculation with $\mathrm{C}$ or the mutant strains (Table 5). We speculate that EMS-induced mutation in T. harzianum triggers down regulation of chlorophyll biosynthesis or salicylic acid (SA) signaling genes in inoculated chili pepper plants. Salicylic acid is a phytohormone that is involved in regulating photosynthetic reactions, transpiration rate and chlorophyll content, which decline under abiotic stress (Singh and Gautam, 2013). Inoculation of wheat plants with Trichoderma longibrachiatum enhances salt tolerance and chlorophyll contents (Zhang et al., 2016). Regarding carotenoids determination, nonsignificant $(\mathrm{P} \leq 0.05)$ differences were found between treatments (Table 5).

To gain further understanding of the biochemical compounds involved in stress tolerance and signaling, the content of total phenols in chili pepper plants inoculated with T. harzianum mutants was determined $9 \mathrm{~d}$ after drought stress (Table 5). Nonsignificant $(\mathrm{P} \leq 0.05)$ differences in total plant phenols content were found when inoculating with all the different mutant strains. It is well established that phenol accumulation is closely related to phenylpropanoid induction pathways and tolerance to drought stress (Hura et al., 2012).

Table 5. Physiological and biochemical tests of 'Jalapeño' pepper plants under drought stress inoculated with Trichoderma harzianum.

\begin{tabular}{|c|c|c|c|c|c|c|c|c|c|}
\hline \multirow[b]{2}{*}{ Strains } & \multirow[b]{2}{*}{ RWC \%* } & \multirow[b]{2}{*}{ RWC } & \multicolumn{3}{|c|}{ Chlorophyll } & \multirow[b]{2}{*}{ Carotenoids } & \multirow[b]{2}{*}{ Phenols } & \multirow[b]{2}{*}{ Proline } & \multirow[b]{2}{*}{ Catalase } \\
\hline & & & $\mathrm{a}$ & $\mathrm{b}$ & $\mathrm{T}$ & & & & \\
\hline & & $\%$ & & $\mathrm{mg} \mathrm{g}^{-1}$ & & $\mathrm{mg} \mathrm{g}^{-1}$ & $\mathrm{mg} \mathrm{g}^{-1}$ & $\mu \mathrm{g} \mathrm{g}^{-1}$ & $\begin{array}{l}\mathrm{U} \mathrm{mg}^{-1} \\
\text { protein }\end{array}$ \\
\hline M5 & $84.6 \mathrm{a}$ & $78.3 b$ & $5.0 \mathrm{a}$ & $3.0 \mathrm{a}$ & $8.1 \mathrm{a}$ & $1.5 \mathrm{ab}$ & $286.2 \mathrm{~b}$ & $399.8 \mathrm{a}$ & $0.0 \mathrm{a}$ \\
\hline M7 & $80.2 \mathrm{a}$ & $78.1 \mathrm{~b}$ & $6.3 \mathrm{ab}$ & $4.3 \mathrm{a}$ & $10.6 \mathrm{ab}$ & $1.3 \mathrm{a}$ & $358.3 \mathrm{~b}$ & 439.8ab & $0.3 \mathrm{a}$ \\
\hline M14 & $83.4 \mathrm{a}$ & $77.0 \mathrm{~b}$ & $9.6 \mathrm{bc}$ & $6.4 \mathrm{ab}$ & $15.9 \mathrm{~b}$ & $2.1 \mathrm{ab}$ & $368.8 \mathrm{~b}$ & $519.7 \mathrm{ab}$ & $0.2 \mathrm{a}$ \\
\hline M21 & $85.0 \mathrm{a}$ & $78.6 \mathrm{bc}$ & $9.3 \mathrm{bc}$ & $5.9 \mathrm{a}$ & $15.2 b$ & $1.7 \mathrm{ab}$ & $169.8 \mathrm{a}$ & $739.6 c$ & $0.1 \mathrm{a}$ \\
\hline M24 & $85.2 \mathrm{a}$ & $82.9 \mathrm{c}$ & $11.0 \mathrm{c}$ & $5.2 \mathrm{a}$ & $16.2 b$ & $2.7 \mathrm{~b}$ & $315.7 \mathrm{~b}$ & $939.5 \mathrm{~d}$ & $0.0 \mathrm{a}$ \\
\hline WT & $84.5 \mathrm{a}$ & $76.3 b$ & $14.5 \mathrm{~d}$ & $10.5 \mathrm{~b}$ & $25.0 \mathrm{c}$ & $2.2 \mathrm{ab}$ & $254.7 \mathrm{ab}$ & $419.8 \mathrm{ab}$ & $0.1 \mathrm{a}$ \\
\hline $\mathrm{C}$ & $84.1 \mathrm{a}$ & $77.1 \mathrm{~b}$ & 7.3ab & $4.4 \mathrm{a}$ & $11.7 \mathrm{ab}$ & $1.7 \mathrm{ab}$ & $294.2 \mathrm{~b}$ & $379.8 \mathrm{a}$ & $0.3 \mathrm{a}$ \\
\hline NT & $78.8 \mathrm{a}$ & $71.1 \mathrm{a}$ & $9.2 \mathrm{bc}$ & 7.2ab & $16.4 \mathrm{~b}$ & $1.6 \mathrm{ab}$ & $297.8 \mathrm{~b}$ & $599.7 \mathrm{bc}$ & $0.1 \mathrm{a}$ \\
\hline
\end{tabular}

M5, M7, M14, M21, M24: Mutant strains; WT: THITR01 wild type strain; C: commercial strain; NT: uninoculated plants.

*All measured parameters were conducted $9 \mathrm{~d}$ after subjecting 'Jalapeño' plants to drought stress, except for relative water content (RWC) which was also determined before drought stress. Chlorophyll (a, b or total, T), carotenoids, phenols and proline are related to dry plant material $(\mathrm{g})$.

Values are means of five biological replicates. For each column, values followed by different letters are significantly different according to Tukey's test $(\mathrm{P} \leq 0.05)$. 
As first attempt to dissect the mechanism used by the chili pepper plant to adapt to drought stress when it is inoculated with the T. harzianum mutants, the proline content was determined. After $9 \mathrm{~d}$ without watering, plants inoculated with the M24 mutant accumulated $939.5 \mu \mathrm{g} \mathrm{g}^{-1}$, which represents a significant $(\mathrm{P} \leq 0.05)$ increase compared to all other inoculated plants (Table 5). Proline can play a role as an osmoprotectant molecule and is widely distributed in plants. Finally, the catalase enzymatic activity was measured to assess if a detoxification mechanism of reactive oxygen compounds was involved (Ahmad et al., 2015). Nonsignificant $(\mathrm{P} \leq 0.05)$ differences were found between the plants inoculated with different Trichoderma strains (Table 5). The molecular pathway that the chili pepper plant uses to adapt to drought stress when inoculated with the mutants described in this work is unknown and could be investigated using a transcriptomic study.

\section{CONCLUSIONS}

Trichoderma harzianum THITR01 mutagenized with ethyl methanesulfonate (EMS) generated strains that have an enhanced antagonist ability in vitro against different soil fungal pathogens. Although these mutant strains are not plant growth promoters, under unavailable P growth conditions the M7 and M14 mutants had the ability to solubilize unavailable $\mathrm{P}$ in the substrate. Only the M14 promoted lateral root formation and root hair elongation in chili pepper plants, which are important to increase absorptive surface to facilitate nutrient uptake. M14 and M21 mutants led to a plant increase in their root fresh and dry weight. On the other hand, the M24 mutant induced proline accumulation in chili pepper plants subjected to drought stress, and display a higher relative water content, important parameters to mitigate drought stress. Therefore, the M14, M21 and M24 mutants could potentially be used as a biocontrol agent in the field for crops that are subjected to fungal diseases and abiotic stress. Further molecular characterization of these mutants might allow its genetic mapping and unravel its signaling mechanism.

\section{ACKNOWLEDGEMENTS}

We thank the National Council of Science and Technology (CONACYT)-Mexico for a scholarship (455491) for E.C.-C. This research was supported by grants from Tecnológico Nacional de México (TecNM)-México ( ${ }^{\circ}$ 6795.18-P) and CONACYT-México ( ${ }^{\circ}$ A1-S-9815) to the corresponding author.

\section{REFERENCES}

Abbasi, S., Safaie, N., Shams-Bakhsh,M., and Shahbazi,S.2016. Biocontrol activities of gamma induced mutants of Trichoderma harzianum against some soilborne fungal pathogens and their DNA fingerprinting. Iran Journal of Biotechnology 14:e1224.

Ahmad, P., Hashem, A., Abd-Allah, E.E., Alqarawi, A.A., John, R., Egamberdieva, D., et al. 2015. Role of Trichoderma harzianum in mitigating $\mathrm{NaCl}$ stress in Indian mustard (Brassica juncea L.) through antioxidative defense system. Frontiers in Plant Science 6:868.

Alfiky, A. 2019. Effects of ultraviolet irradiation on the in vitro antagonistic potential of Trichoderma spp. against soil-borne fungal pathogens. Heliyon 5:e02111.

Alori, E.T., Glick, B.R., and Babalova, O.O. 2017. Microbial phosphorus solubilization and its potential for use in sustainable agriculture. Frontiers in Plant Science 8:971.

Baron, N.C., Rigobelo, E.C., and Zied, D.C. 2019. Filamentous fungi in biological control: current status and future perspectives. Chilean Journal of Agricultural Research 79:307-315.

Barros, V., Frosi, G., Santos, M., Ramos, D.G., Falcão, H.M., and Santos, M.G. 2018. Arbuscular mycorrhizal fungi improve photosynthetic energy use efficiency and decrease foliar construction cost under recurrent water deficit in woody foliar construction cost under recurrent water deficit in woody. Plant Physiology and Biochemistry 127:469-477.

Cai, F., Chen, W., Wei, Z., Pang, G., Li, R., Ran, W., et al. 2015. Colonization of Trichoderma harzianum strain SQR-T037 on tomato roots and its relationship to plant growth, nutrient availability and soil microflora. Plant and Soil 388:337-350.

Carpi, F.M., Di Pietro, F., Vincenzetti, S., Mignini, F., and Napolioni V. 2011. Human DNA extraction methods: Patents and applications. Recent Patents on DNA \& Gene Sequences 5:1-7.

Carvalhais, L.C., Dennis, P.G., Badri, D.V., Kidd, B.N., Vivanco, J.M., and Schenk, P.M. 2015. Linking jasmonic acid signaling, root exudates, and rhizosphere microbiomes. Molecular Plant Microbe Interactions 28:1049-1058.

Contreras-Cornejo, H.A., Macías-Rodríguez, L., Alfaro-Cuevas, R., and López-Bucio, J. 2014. Trichoderma spp. improve growth of Arabidopsis seedlings under salt stress through enhanced root development, osmolite production, and $\mathrm{Na}^{+}$ elimination through root exudates. Molecular Plant Microbe Interactions 27:503-514. 
Druzhinina, I., Seidl-Seiboth, V., Herrera-Estrella, A., Horwitz, B., Kenerley, C., Monte, E., et al. 2011. Trichoderma the genomics of opportunistic success. Nature Reviews Microbiology 9:749-759.

Feitosa, Y., Cruz-Magalhães, V., Argolo-Filho, R.C., de Souza, J.T., and Loguercio, L.L. 2019. Characterization of genetic diversity on tropical Trichoderma germplasm by sequencing of rRNA internal transcribed spacers. BMC Research Notes $12: 663$.

Guler, N.S., Pehlivan, N., Karaoglu, S.A., Guzel, S, and Bozdeveci, A. 2016. Trichoderma atroviride ID20G inoculation ameliorates drought stress-induced damages by improving antioxidant defence in maize seedlings. Acta Physiologiae Plantarum 38:132.

Guo, R., Wang, W., Huang, Y., Fan, H., and Liu, Z. 2018. Biocontrol potential of saline- or alkaline-tolerant Trichoderma asperellum mutants against three pathogenic fungi under saline or alkaline stress conditions. Brazilian Journal of Microbiology 49S:236-245.

Halifu, S., Deng, X., Song, X., and Song, R. 2019. Effects of two Trichoderma strains on plant growth, rhizosphere soil nutrients, and fungal community of Pinus sylvestris var. mongolica annual seedlings. Forests 10:758.

Ham, B.-K., Chen, J., Yan, Y., and Lucas, W.J. 2018. Insights into plant phosphate sensing and signaling. Current Opinion in Biotechnology 49:1-9.

Hobbie, S.E., Finlay, J.C., Janke, B.D., Nidzgorski, D.A., Millet, D.B., and Baker, L.A. 2017. Contrasting nitrogen and phosphorus budgets in urban watersheds and implications for managing urban water pollution. Proceedings of the National Academy of Sciences of the United States of America 114:4177-4182.

Hura, T., Hura, K., Dziurka, K., Ostrowska, A., Baczek-Kwinta, R., and Grzesiak, M. 2012. An increase in the content of cell wall-bound phenolics correlates with the productivity of triticale under soil drought. Journal of Plant Physiology 169:1728-1736.

Keswani, C., Mishra, S., Sharma, B.K., Singh, S.P., and Singh, H.B. 2014. Unraveling the efficient applications of secondary metabolites of various Trichoderma spp. Applied Microbiology and Biotechnology 98:533-544.

Koralage, I., Weerasinghe, P., Silva, N., and Silva, C. 2015. The determination of available phosphorus in soil: a quick and simple method. Open University of Sri Lanka Journal 8:1-17.

Li, R.-X., Cai, F., Pang, G., Shen, Q.R., Li, R., and Chen, W. 2015. Solubilisation of phosphate and micronutrients by Trichoderma harzianum and its relationship with the promotion of tomato plant growth. PLOS ONE 10:e0130081.

Maurya, S., Eram, R.-E., Naik, S.K., Choudhary, J.S., and Kumar, S. 2019. Heavy metals scavenging potential of Trichoderma asperellum and Hypocrea nigricans isolated from acid soil of Jharkhand. Indian Journal of Microbiology 59:27-38.

Niu, Y.F., Chai, R.S., Jin, G.L., Wang, H., Tang, C.X., and Zhang, Y.S. 2013. Responses of root architecture development to low phosphorus availability: a review. Annals of Botany 112:391-408.

Poosapati,S., Ravulapalli,P.D., Tippirishetty, N., Vishwanathaswamy,D.K., and Chunduri, S. 2014. Selection of high temperature and salinity tolerant Trichoderma isolates with antagonistic activity against Sclerotium rolfsii. Springer Plus 3:641.

Rawat, R., and Tewari, L. 2011. Effect of abiotic stress on phosphate solubilization by biocontrol fungus Trichoderma sp. Current Microbiology 62:1521-1526.

Ribeiro, O., Magalhães, F., Aguiar, T.Q., Wiebe, M.G., Penttilä, M., and Domingues, L. 2013. Random and direct mutagenesis to enhance protein secretion in Ashbya gossypii. Bioengineered 4:322-331.

Salgado-Aguilar, M., Molnar, T., Pons-Hernández, J.L., Covarrubias-Prieto, J., Ramírez-Pimentel, J.G., Raya-Pérez, J.C., et al . 2020. Physiological and biochemical analyses of novel drought-tolerant maize lines reveal osmoprotectant accumulation at silking stage. Chilean Journal of Agricultural Research 80:241-252.

Singh, P.K., and Gautam, S. 2013. Role of salicylic acid on physiological and biochemical mechanism of salinity stress tolerance in plants. Acta Physiologiae Plantarum 35:2345-2353.

Singh, R., Maurya, S., and Upadhyay, R.S. 2016. The improvement of competitive saprophytic capabilities of Trichoderma species through the use of chemical mutagens. Brazilian Journal of Microbiology 47:10-17.

Singh, D., Singh, V., Gupta, V., Shukla, R., Prabha, R., Sarma, B., et al. 2020. Microbial inoculation in rice regulates antioxidative reactions and defense related genes to mitigate drought stress. Scientific Reports 10:4818.

Vinale, F., Nigro, M., Sivasithamparam, K., Flematti, G., Ghisalberti, E., Ruocco, M., et al. 2013. Harzianic acid: a novel siderophore from Trichoderma harzianum. FEMS Microbiology 347:123-129.

Wu, Q., Sun, R., Ni, M., Yu, J., Li, Y., Yu, C., et al. 2017. Identification of a novel fungus, Trichoderma asperellum GDFS1009, and comprehensive evaluation of its biocontrol efficacy. PLOS ONE 12:e0179957.

Zeilinger, S., Gruber, S., Bansal, R., and Mukherjee, P.K. 2016. Secondary metabolism in Trichoderma - Chemistry meets genomics. Fungal Biology Reviews 30:74-90.

Zhang, S., Gan, Y., and Xu, B. 2016. Application of plant-growth-promotion fungi Trichoderma longibrachiatum T6 enhances tolerance of wheat to salt stress through Improvement of antioxidative defense system and gene expression. Frontiers in Plant Science 7:1405.

Zin, N.A., and Badaluddin, N.A. 2020. Biological functions of Trichoderma spp. for agriculture applications. Annals of Agricultural Sciences 65:168-178. 